\title{
EMISSION MEASUREMENTS OF GEOGENIC GREENHOUSE GASES IN THE AREA OF "PUSTY LAS" ABANDONED OILFIELD (POLISH OUTER CARPATHIANS)
}

\author{
Piotr Guzy', Dawid Pietrzycki², Anna Świerczewska', \\ Henryk Sechman', Anna Twaróg' ${ }^{1}$, Adrianna Góra'
}

\author{
1 AGH-University of Science and Technology, Faculty of Geology Geophysics and Environmental Protection, \\ Department of Fossil Fuels, Al. Mickiewicza 30, 30-059 Kraków, Poland, e-mail: piotrgu@agh.edu.pl \\ 2 LOTOS Petrobaltic S.A., ul. Stary Dwór 9, 80-758 Gdańsk, Poland
}

Received: 2017.05 .06 Accepted: 2017.06.01 Published: 2017.07.01

\begin{abstract}
The Carpathians may play a significant role as a supplier of greenhouse gases to the atmosphere. Unfortunately, most of the discovered oil and gas deposits are recently only historical objects. An example is the Sękowa-Ropica Górna-Siary oil deposit located in the marginal part of the Magura Nappe where oil had been extracted in dug wells until the mid XX century. One of such extraction sites is the "Pusty Las" oilfield. In that area, 10 methane and carbon dioxide emission measurement sites were located, among which 4 in dried dug wells and 6 in dig wells still filled with oil and/or water. Dynamics of methane and carbon dioxide concentration changes were measured with the modified static chambers method. Gas samples were collected immediately after the installation of the chamber and again, after 5 and 10 minutes. In the case of reclaimed or dry dug wells, static chamber was installed directly at the ground surface. In wells still filled with oil and/or water the chamber was equipped with an "apron" mounted on special sticks. The dynamics of concentrations changes varied from -0.871 to $119.924 \mathrm{ppm} \cdot \mathrm{min}^{-1}$ for methane and from -0.005 to $0.053 \%$ $\mathrm{obj} \cdot \mathrm{min}^{-1}$ for carbon dioxide. Average methane emission was $1.9 \mathrm{~g} \cdot \mathrm{m}^{-2} \cdot \mathrm{d}^{-1}$ and that of carbon dioxide was $26.95 \mathrm{~g} \cdot \mathrm{m}^{-2} \cdot \mathrm{d}^{-1}$. The measurements revealed that an abandoned oil field supplies significant amounts of greenhouse gases to the atmosphere although the emission of methane is lower than that measured e.g. in mud volcanoes located in various parts of the world.
\end{abstract}

Keywords: greenhouse gas, methane, carbon dioxide, Outer Carpathians

\section{INTRODUCTION}

The emission of geogenic methane and carbon dioxide is regarded as one of the reasons of global climate changes. The results of studies run worldwide indicate that gas emissions from such sources strongly contribute to the increasing concentrations of greenhouse gases in the atmosphere, among which methane and carbon dioxide play crucial roles [Mazzini et al., 2009; Hong et al., 2009].

The emission of methane sourced by hydrocarbon generation and expulsion in petroleum basins is quoted as one of the two types of methane release to the atmosphere controlled by geological factors. Recently, it shares about $7-14 \%$ of global annual methane emission (from $\sim 40$ to 60 $\mathrm{Tg} \mathrm{CH}_{4}$ /year). In Europe, total methane emission from seepages reaches about $3 \mathrm{Tg} /$ year [Etiope, 2008]. The soil-to-atmosphere emission of carbon dioxide may result from bacterial oxidation of $\mathrm{CH}_{4}$ or from migration from endogenic sources or from $\mathrm{CO}_{2}$ generation under anoxic conditions, simultaneously with the methane [Waleńczak, 1987]. Other examples of geogenic sources of gas emissions can be mud volcanoes and/or geothermal systems. 
Hydrocarbon seepages are the most typical evidences of hydrocarbon potential of petroleum basins. The Outer Carpathians are the area of significant petroleum potential, as revealed by both the macro- and microseepages, and gas exhalations [Kuśmierek et al., 2007; Kuśmierek and Machowski, 2008; Lipińska 2010]. The hydrocarbon macroseeps are typical of petroleum basins of complicated tectonics and are observed mostly in the elevated, axial zones of fold structures, and in dislocation zones. Hydrocarbon migration from deep accumulations to the nearsurface zone is predominantly controlled by diffusion and effusion [e.g.: Jones and Drozd, 1983; Matthews, 1996]. Hence, the Carpathians may be a regional source of supply of greenhouse gases to the atmosphere.

In the early years of modern petroleum exploration, hydrocarbon seeps were the first prospection premises in many world-famous basins, including the Carpathians. Even before the World War II most of petroleum wells from which commercial inflows of oils and gas were obtained, were localized within the zones of natural hydrocarbon seeps [Link, 1952].

In the Carpathians, hydrocarbons have been commercially exploited since the mid $\mathrm{XIX}^{\text {th }}$ century. The peak oil production from the Carpathian fields was obtained in 1909 (over 2 Mt) [Karnkowski, 1999]. An example of such a field where oil was worked from shallow dug wells is the Sękowa-Ropica Górna-Siary deposit, which operated until the mid $\mathrm{XX}^{\text {th }}$ century. The deposit is located at the marginal zone of the Magura Unit. The name of the exploitation site is the "Pusty Las" ("Empty Forest") [Pietrzycki, 2013].

The present paper aims to estimate the quantity of methane and carbon dioxide emission to the atmosphere from old, inactive dug wells located in the area of the "Pusty Las" oil site.

\section{STUDY AREA}

The study area is located in the Sękowa Commune, in the Gorlice County of the Małopolska District. From geological point of view, this area belongs to the Outer Carpathians, precisely, to the marginal zone of the Magura Unit (the Siary Sub-unit) (Fig. 1).

\section{Geological setting}

The Magura Unit is the structurally highest and southwardmost tectonic unit of the Outer Carpathians. From the south, it borders the Pieniny Klippen Belt and from the north it is thrusted over the Fore-Magura and the Silesian units [Oszczypko, 2004].

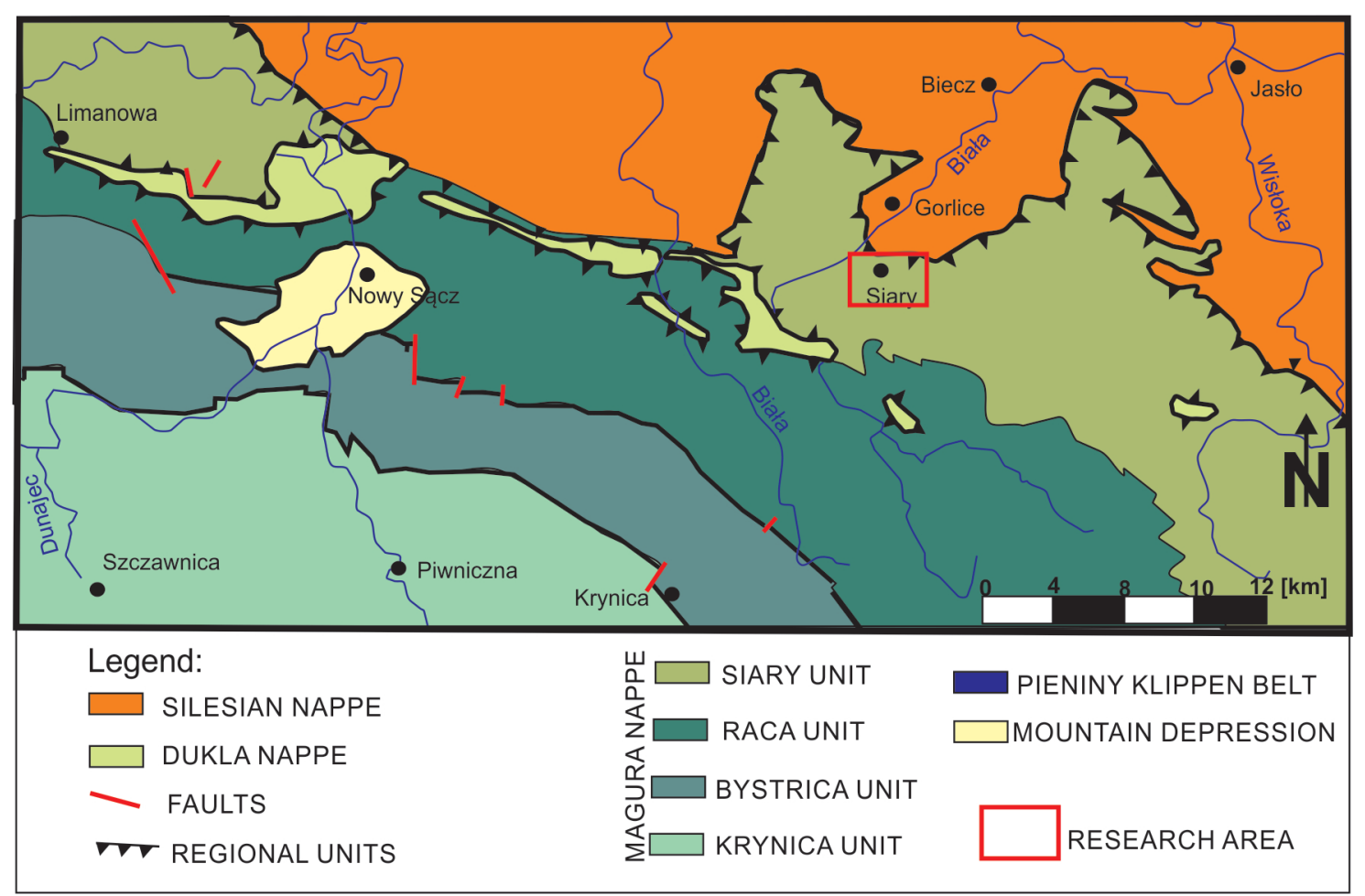

Figure. 1. Geological sketch of research area (Żytko et al., 1989; Świerczewska, 2005; modificated) 
The Magura Unit comprises four sub-units (from the south): Krynica, Bystrica, Raca and Siary [Birkenmajer, 1977]. The rocks observed at the surface are mostly the Paleogene sediments. In the Siary Sub-unit, the oldest member is named the Ropianka Beds (=Inoceramus Beds) followed by the Łabowa Shales Formation [Ryłko, 2004], in which the two members were distinguished: the Skawce Sandstones and the Pasierbiec Sandstones [Oszczypko-Clowes, 2001, Ryłko, 2004]. Within the Siary zone, the Magura Beds directly cover the variegated shales of the Labowa Formation. Lithologically, these are sandstones and shales [Książkiewicz, 1972; Oszczypko-Clowes, 1999]. The Magura beds are overlain by the Gładyszów beds (uppermost Lower Oligocene) [Kopciowski and Garecka, 1996].

Generally, the Magura Unit is less hydrocarbon-prone unit in the whole Outer Carpathians [Karnkowski, 1999].

\section{The Sękowa-Ropica Górna-Siary oil deposit}

In the area of the Sękowa-Ropica Górna-Siary deposit, three oil exploitation sites (traditionally named "oil mines") are known: "Pusty Las", "Sękowa" and "Ropica Górna". Totally, 785 wells were completed here. Hydrocarbon exploration had continued until 1939. The oil was reservoired in sandstones of the Inoceramus Beds, at depth interval from 11 to 700 meters. Estimated total production was about 208000 metric tons from assessed area of $1.77 \mathrm{~km}^{2}$ [Karnkowski, 1999].

\section{METHODOLOGY OF FIELD AND LABORATORY WORKS}

\section{Field works}

The studies were carried out in the area of Pusty Las "oil mine". In this area some oil dugwells have already been closed, i.e., entirely filled up with rubble, some others were still empty (or "open") and, thus, recognizable as hollows of various size.

In the field studies, the modified static chamber method was applied [Leventhal, 1992; Dzieniewicz et al., 2002; Korus et al., 2005; Sechman et al., 2006], in which gas is collected in predefined time intervals from the inner space of closed chamber installed at the terrain surface. For sampling of dug wells filled with oil and/or water, the chamber rested over the open space on two transversal levers. The chamber itself is a vessel of the volume of $48 \mathrm{dm}^{3}$, made of stainless steel and it is provided with a sealed opening to allow a sample of gas from the interior volume of the chamber. The area directly covered by the chamber is $28.27 \mathrm{dm}^{2}$.

For gas sampling, 10 sites were selected (Table 1) from which 4 sites were filled-up (closed) dug wells (sites Nos. 1, 2, 3 and 4) and next 6 were open dug wells (sites Nos. 5, 6, 7, 8, 9 and 10). The earlier experiments [Sechman and Dzieniewicz, 2009] demonstrated that the highest dynamics of changes in gas concentrations occur in time intervals from 0 to 10 minutes since chamber installation. Hence, at each site, gas was sampled immediately after chamber setting, then after 5 and after 10 minutes. Overall, during the tests 30 samples of gas from chambers were collected. During the sampling, the atmospheric pressure was measured together with soil temperature at $10 \mathrm{~cm}$ depth. Gas samples were pumped to special glass vessels filled with brine [Dzieniewicz and Sechman, 2002]. Totally, 30 gas samples were collected from 10 sampling sites. Additionally, atmospheric air sample was taken from the area of the "oil mine". The field works were run in the area of the Pusty Las "oil mine" in April, 2013

In the case of closed dug wells, the rubbish and outer, 10-cm-thick soil layer were removed, and the chamber was pressed into the ground. The chamber walls contacting the ground were sealed (Fig. 3A). As the chamber could not be installed directly in the dug wells filled with oil and/or water, it was equipped with a special "apron" and placed over the well space onto the two transversal bars (Fig. 3B).

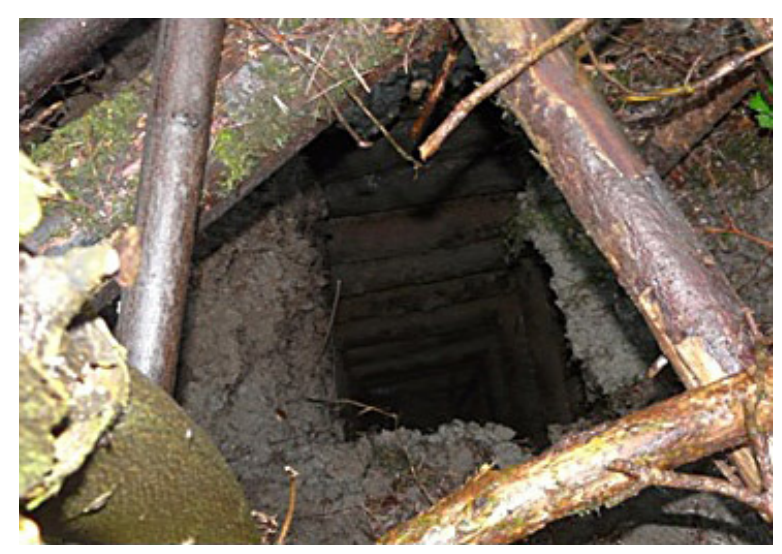

Figure 2. Example of timbering, open dug wells (site No. 6) (Fot. D. Pietrzycki) 
Table 1. Principal statistical parameters of alkanes and carbon dioxide concentrations calculated for all-30 measurements

\begin{tabular}{|c|c|c|c|c|c|c|c|c|c|}
\hline \multirow{2}{*}{$\begin{array}{l}\text { Stat. parm. } \\
\text { (ppm) }\end{array}$} & \multicolumn{8}{|c|}{ Alkanes } & \multirow{2}{*}{$\mathrm{CO}_{2}{ }^{* *}$} \\
\hline & $\mathrm{CH}_{4}$ & $\mathrm{C}_{2} \mathrm{H}_{6}$ & $\mathrm{C}_{3} \mathrm{H}_{8}$ & $i-\mathrm{C}_{4} \mathrm{H}_{10}$ & $n-\mathrm{C}_{4} \mathrm{H}_{10}$ & neo- $\mathrm{C}_{5} \mathrm{H}_{12}$ & $i-\mathrm{C}_{5} \mathrm{H}_{12}$ & $n-\mathrm{C}_{5} \mathrm{H}_{12}$ & \\
\hline Min & 0.8 & b.d.I. & b.d.I. & b.d.l. & b.d.I. & b.d.l. & b.d.I. & b.d.I. & $0.07^{* *}$ \\
\hline Max & 1220.0 & 3.62 & 3.50 & 0.77 & 0.65 & 0.01 & 0.41 & 0.05 & $0.22^{\star *}$ \\
\hline Mean & 65.4 & 0.25 & 0.16 & 0.04 & 0.03 & 0.000 & 0.02 & b.d.I. & $0.12^{* *}$ \\
\hline Stand. dev. & 221.0 & 0.69 & 0.62 & 0.14 & 0.16 & b.d.l. & 0.08 & 0.01 & $0.04^{* *}$ \\
\hline Median & 3.1 & b.d.I. & b.d.I. & b.d.I. & b.d.I. & b.d.l. & b.d.l. & b.d.I. & $0.12^{* *}$ \\
\hline $\begin{array}{l}\text { Percentage of } \\
\text { samples* }\end{array}$ & 100 & 38.7 & 19.4 & 19.4 & 16.1 & 3.2 & 16.1 & 16.1 & 100 \\
\hline
\end{tabular}

*-percentage of samples with concentration of given component over detection limit; ** - minimum, maximum, mean, median and standard deviation in vol.\%, b.d.l. - below detection limit (detection limit for hydrocarbons is $0.01 \mathrm{ppm}$ and $100 \mathrm{ppm}$ for carbon dioxide).
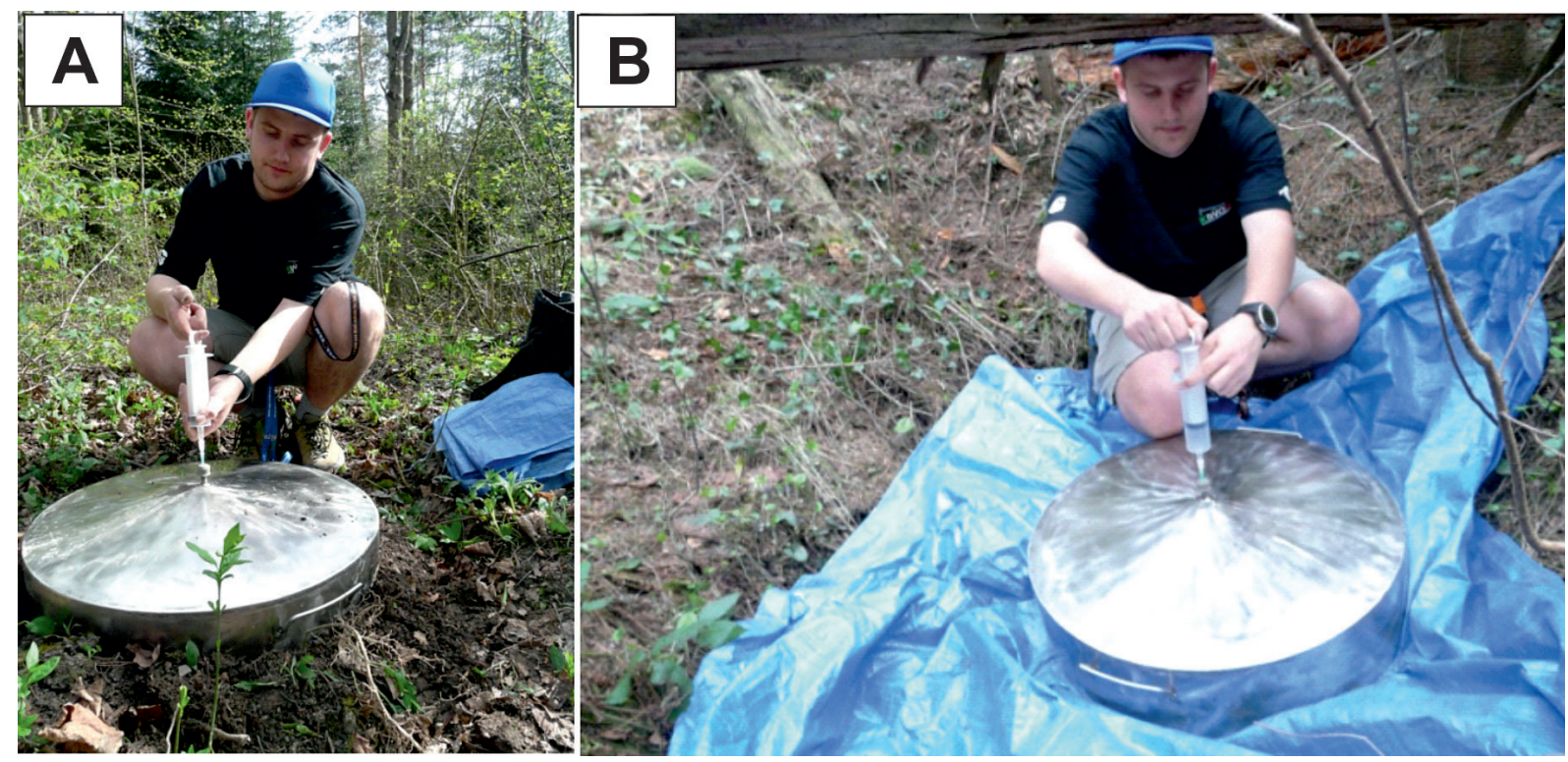

Figure 3. Measurements within the filled-up dug wells (A) and open dug wells (B) (Fot. D. Pietrzycki)

\section{Laboratory tests}

The molecular composition of gas samples were analyzed at the Laboratory of Gas Chromatography of the Department of Fossil Fuels. We used FISSONS Instruments GC 8160 and CARLO ERBA Instruments GC 6300 gas chromatographs equipped with FID and TCD detectors. In each sample, methane, ethane, propane, $i$-butane, $n$-butane, neo-pentane, $i$-pentane, $n$-pentane, ethylene, propylene, 1 -butene and carbon dioxide were determined. Detection limit for FID is 0.01 ppm for hydrocarbons. Analytical precision is $2 \%$ of measured value and $10 \%$ at detection limit. TCD detection limits for carbon dioxide is 100 ppm and estimated precision is $2 \%$ of measured value and $10 \%$ at detection limit.

\section{METHODOLOGY OF STATISTICAL ANALYSIS AND RESULTS PRESENTATION}

The populations of measured concentrations of gaseous hydrocarbons were initially characterized by determination of basic statistical parameters, calculated for all the obtained results and separately, for samples collected over the closed and the open dug wells. The relationships between measured methane and carbon dioxide concentrations were evaluated using the correlation plots based upon the cartesian coordinates XY system. Such plots were constructed for the whole results and separately, for the results for closed and open dug wells. In order to evaluate the dynamics of changes in concentrations of methane and carbon dioxide, linear plots were drawn, which illustrated 
the changes of gas concentrations in time. Then, computer-generated, linear trend of concentration changes was overprinted on the plots. For the trend lines, the coefficient of determination $\mathrm{R}^{2}$ was calculated. For both the methane and carbon dioxide, results were noted in ppm and in volume percents per minute. The emission was expressed in milligrams per square meter per day for methane emission and in grams per square meter per day for carbon dioxide emisssion.

\section{METHODOLOGY OF EMISSION CALCULATION}

The quantities of methane and carbon dioxide emissions were calculated using the formula established during the previous geochemical surveys [Korus et al., 2002; Dzieniewicz et al., 2006; Sechman and Dzieniewicz, 2009]. If the collection chamber was installed at the ground surface the area covered by the chamber was constant. If the collector was mounted over the open dug wells the chamber parameter depended on the changing surface covered by the "apron".

\section{RESULTS AND DISCUSSION}

\section{Statistical characterization of population of all measured gas concentrations.}

In the analyzed gas samples, saturated hydrocarbons $\mathrm{C}_{1}-\mathrm{C}_{5}$ and carbon dioxide were detected. Methane concentrations varied from 0.81 to $1220 \mathrm{ppm}$. Maximum ethane concentration was $3.62 \mathrm{ppm}$ and this gas was found in almost $40 \%$ of the analyzed samples. Propane occurred in $19.4 \%$ of the analyzed samples and its values reached $3.5 \mathrm{ppm}$ with the mean value 0.16 ppm. The same percentage of samples contained i-butane whereas i-pentane and n-pentane were detected in over $16 \%$ of the analyzed samples. Maximum butane and pentanes concentrations did not exceed 1 ppm. Trace amounts of ethylene were measured in only two samples whereas the remaining gaseous alkenes were absent in the analyzed material. The concentrations of carbon dioxide varied from 0.07 to 0.22 vol. $\%$ with the mean value 0.12 vol.\% (Table 1 ).

Concentrations of methane and carbon dioxide measured in the atmospheric air from the area of the Pusty Las site were 3.68 ppm and 0.09 vol.\%, respectively. For comparison, the average concentration of atmospheric methane is about $2 \mathrm{ppm}$ and that of carbon dioxide is about 0.03 vol.\%. Moreover, concentrations of methane and carbon dioxide measured over the closed bituminous coal mines in the Wałbrzych mining district (SW Poland) were $5 \mathrm{ppm}$ and 0.05 vol.\%, respectively [Korus et al. 2002], and methane concentration measured in the atmospheric air sampled immediately over the mud volcano from Azerbeijan was 99.65 vol.\%. [Mazzini et al., 2009].

\section{Statistical characterization of gas concentrations in samples collected from over the closed oil dug wells}

In gas samples collected from the closed oil dug wells, methane, ethane, propane, i-butane, ipentane, $n$-pentane and carbon dioxide were detected. Methane was found in all of the analyzed samples, in concentrations from 0.8 to $1220 \mathrm{ppm}$ with arithmetic mean $125.4 \mathrm{ppm}$ and median value $3 \mathrm{ppm}$. Ethane was detected in almost $42 \%$ of analyzed samples in concentrations up to $3.62 \mathrm{ppm}$ (arithmetic mean $-0.4 \mathrm{ppm}$ ). Propane was observed in almost $17 \%$ of the analyzed samples. Its concentrations reached up to $3.5 \mathrm{ppm}$ with arithmetic mean $0.32 \mathrm{ppm}$. Maximum concentrations of i-butane and n-butane were 0.77 and $0.65 \mathrm{ppm}$, respectively, and were observed in almost $17 \%$ of the analyzed samples. Neo-pentane has not been detected whereas i-petane and n-pentane were observed in about $17 \%$ of the analyzed samples, but in amounts below $0.5 \mathrm{ppm}$. The concentrations of carbon dioxide varied from 0.07 to 0.22 vol. $\%$ with the arithmetic mean 0.14 vol.\% (Table 2) .

\section{Statistical characterization of gas concentrations in samples collected from over the open oil dug wells}

In gas samples collected from the open oil dug wells, methane, ethane, propane, i-butane, neo-pentane, i-pentane, n-pentane and carbon dioxide were detected. Methane was observed in all of the analyzed samples, in concentrations from 1.41 to $288.5 \mathrm{ppm}$ with arithmetic mean $28.7 \mathrm{ppm}$ and median value $2.9 \mathrm{ppm}$. Ethane was found in almost $40 \%$ of the analyzed samples, in concentrations up to $1.23 \mathrm{ppm}$ (arithmetic mean -0.06 $\mathrm{ppm}$ ). Propane was detected in over $22 \%$ of analyzed samples, in concentrations up to $0.44 \mathrm{ppm}$ (arithmetic mean $-0.06 \mathrm{ppm}$ ). Neo-pentane was detected in a single sample (0.008 ppm).Maxi- 
Table 2. Principal statistical parameters of alkanes and carbon dioxide concentrations calculated for closed dug wells (12 results)

\begin{tabular}{|c|c|c|c|c|c|c|c|c|c|}
\hline \multirow{2}{*}{$\begin{array}{l}\text { Stat. parm. } \\
\text { (ppm) }\end{array}$} & \multicolumn{8}{|c|}{ Alkanes } & \multirow{2}{*}{$\mathrm{CO}_{2}^{* *}$} \\
\hline & $\mathrm{CH}_{4}$ & $\mathrm{C}_{2} \mathrm{H}_{6}$ & $\mathrm{C}_{3} \mathrm{H}_{8}$ & $i-\mathrm{C}_{4} \mathrm{H}_{10}$ & $n-\mathrm{C}_{4} \mathrm{H}_{10}$ & neo- $\mathrm{C}_{5} \mathrm{H}_{12}$ & $i-\mathrm{C}_{5} \mathrm{H}_{12}$ & $n-\mathrm{C}_{5} \mathrm{H}_{12}$ & \\
\hline Min & 0.8 & b.d.l. & b.d.I. & b.d.l. & b.d.l. & b.d.l. & b.d.l. & b.d.I. & $0.07^{\star *}$ \\
\hline $\operatorname{Max}$ & 1220 & 3.62 & 3.50 & 0.77 & 0.65 & b.d.I. & 0.41 & 0.05 & $0.22^{* *}$ \\
\hline Mean & 125.4 & 0.40 & 0.32 & 0.07 & 0.06 & b.d.I. & 0.04 & 0.01 & $0.14^{* *}$ \\
\hline Stand. dev. & 351.7 & 1.04 & 1.01 & 0.22 & 0.19 & b.d.I. & 0.12 & 0.01 & $0.04^{* *}$ \\
\hline Median & 3.0 & b.d.I. & b.d.I. & b.d.I. & b.d.I. & b.d.l. & b.d.l. & b.d.I. & $0.14^{* *}$ \\
\hline $\begin{array}{l}\text { Percentage of } \\
\text { samples* }\end{array}$ & 100 & 41.7 & 16.7 & 16.7 & 16.7 & 0 & 16.7 & 16.7 & 100 \\
\hline
\end{tabular}

* - percentage of samples with concentration of given component over detection limit; ** - minimum, maximum, mean, median and standard deviation in vol.\%, b.d.l. - below detection limit (detection limit for hydrocarbons is $0.01 \mathrm{ppm}$ and $100 \mathrm{ppm}$ for carbon dioxide).

mum concentrations of i-butane and n-butane were 0.12 and $0.06 \mathrm{ppm}$ respectively. Both ipentane and n-pentane were found in about $16 \%$ of analyzed samples, in concentrations below 0.2 ppm. The concentrations of carbon dioxide varied from 0.07 to 0.15 vol. $\%$ with the arithmetic mean 0.11 vol.\%. (Table 3).

\section{Evaluation of geochemical indicators}

Generally, concentrations of alkanes in analyzed samples decreased with the increasing number of atoms in molecules, which suggests deep origin of these hydrocarbons (Table 1). Concentrations of methane and carbon dioxide were higher in samples taken from above the closed dug wells (Table 2, 3). The lower concentrations of both gases detected over the open dug wells can be related also to the fact that most of the wells were filled with water, which provides a barrier for both gases. Additionally, carbon dioxide, which is heavier than the air, may accumulate in local depressions. The concentrations of methane and carbon dioxide did not reveal correlation (Fig. 4A). However, the coefficient of determination $\mathrm{R}^{2}$ calculated for samples from over the closed dug wells was 0.48 whereas that determined for open wells was only 0.03 (Fig. $4 \mathrm{~B}, \mathrm{C})$. These values suggest that relationships between methane and carbon dioxide concentrations from these sites are much interrelated. It can be explained as an effect of microbial generation of these gases under anoxic conditions. Such a process may operate when the dispersed organic matter is contained in a rubble filling the dug wells. Hence, the newly generated microbial gases contribute to the flux of gases ascending from deep sources. In the open dug wells, carbon dioxide, which is heavier than the atmospheric air, presumably accumulates at the bottoms of the wells whereas methane, which is lighter than the air, readily raised towards the sampling chamber. Moreover, deep-sourced carbon dioxide more intensively dissolves in the water filling the wells that deep-sourced methane, which affects the relationships between both gases.

Table 3. Principal statistical parameters of alkanes and carbon dioxide concentrations calculated for open dug wells (18 results)

\begin{tabular}{|c|c|c|c|c|c|c|c|c|c|}
\hline \multirow{2}{*}{$\begin{array}{l}\text { Stat. parm. } \\
\text { (ppm) }\end{array}$} & \multicolumn{8}{|c|}{ Alkanes } & \multirow{2}{*}{$\mathrm{CO}_{2}{ }^{* *}$} \\
\hline & $\mathrm{CH}_{4}$ & $\mathrm{C}_{2} \mathrm{H}_{6}$ & $\mathrm{C}_{3} \mathrm{H}_{8}$ & $i-\mathrm{C}_{4} \mathrm{H}_{10}$ & $n-\mathrm{C}_{4} \mathrm{H}_{10}$ & neo- $\mathrm{C}_{5} \mathrm{H}_{12}$ & $i-\mathrm{C}_{5} \mathrm{H}_{12}$ & $n-\mathrm{C}_{5} \mathrm{H}_{12}$ & \\
\hline Min & 1.1 & b.d.I. & b.d.I. & b.d.I. & b.d.l. & b.d.I. & b.d.I. & b.d.I. & $0.07^{\star \star}$ \\
\hline Max & 288.5 & 1.23 & 0.44 & 0.12 & 0.06 & 0.01 & 0.12 & 0.02 & $0.15^{* *}$ \\
\hline Mean & 28.7 & 0.16 & 0.06 & 0.02 & 0.01 & b.d.I. & 0.02 & b.d.l. & $0.11^{* *}$ \\
\hline Stand. dev. & 69.9 & 0.36 & 0.13 & 0.04 & 0.02 & b.d.I. & 0.04 & 0.01 & $0.03^{* \star}$ \\
\hline Median & 2.9 & b.d.I. & b.d.I. & b.d.I. & b.d.l. & b.d.l. & b.d.I. & b.d.I. & $0.12^{* \star}$ \\
\hline $\begin{array}{l}\text { Percentage of } \\
\text { samples* }\end{array}$ & 100 & 38.9 & 22.2 & 22.2 & 16.7 & 5.6 & 16.7 & 16.7 & 100 \\
\hline
\end{tabular}

* - percentage of samples with concentration of given component over detection limit; ** - minimum, maximum, mean, median and standard deviation in vol.\%, b.d.l. - below detection limit (detection limit for hydrocarbons is $0.01 \mathrm{ppm}$ and $100 \mathrm{ppm}$ for carbon dioxide). 

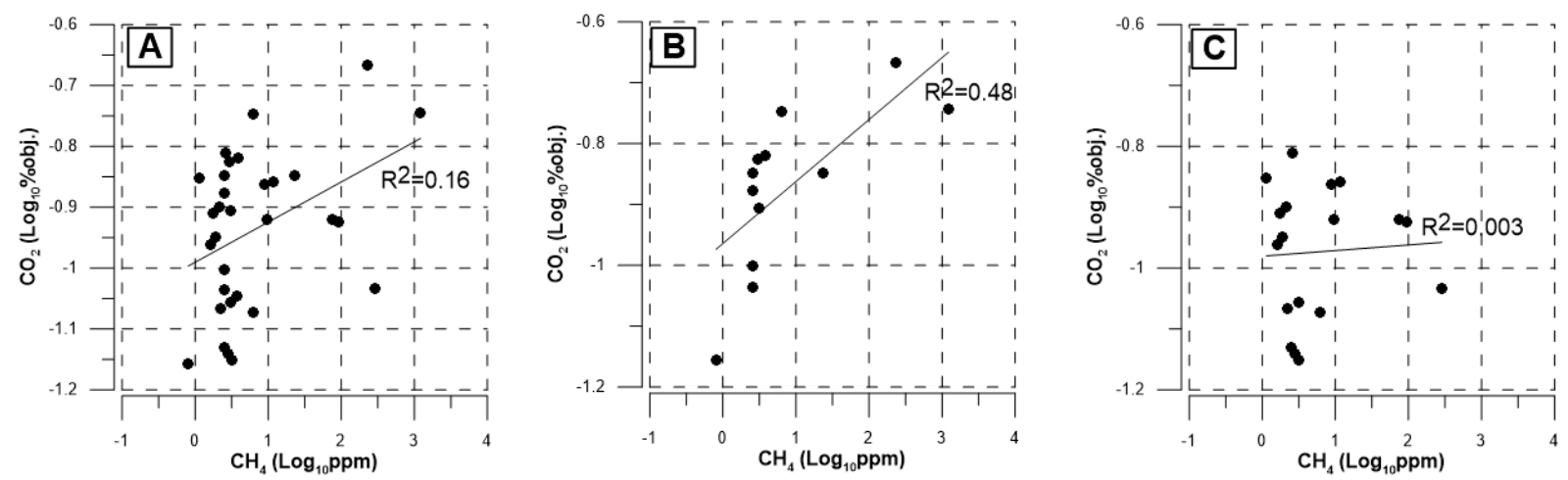

Figure 4.Scatter-plots of methane versus carbon dioxide concentrations for whole dataset (A), data from over the closed oil dug wells (B), data from over the open oil dug wells (B)

\section{Dynamics of changes in concentrations of methane and carbon dioxide, and quantities of their emission}

The dynamics of concentrations changes of methane released to the atmosphere from oil dug wells is expressed by the range of migration rates from -0.87 to $119 \mathrm{ppm} \cdot \mathrm{min}^{-1}$. In $60 \%$ of sampling sites, the increasing trends were observed, in the remaining $40 \%$ the decreasing trend was found. Dynamics of carbon dioxide concentration changes is illustrated by values from -0.005 to $0.053 \mathrm{vol} . \% \cdot \mathrm{min}^{-1}$. The trends of $\mathrm{CO}_{2}$ concentration changes were identical as those for methane (Fig. 4).

The emission values of methane varied from -7.8 to $18660 \mathrm{mg} \cdot \mathrm{m}^{-2} \cdot \mathrm{d}^{-1}$ for closed dug wells and from -62.2 to $42.4 \mathrm{mg} \cdot \mathrm{m}^{-2} \cdot \mathrm{d}^{-1}$ for open wells, negative emissions are the result of bacterial destruction of methane [e.g.: Klusman, 1993]. Carbon dioxide showed emission values from about -10 to about $47 \mathrm{~g} \cdot \mathrm{m}^{-2} \cdot \mathrm{d}^{-1}$ for closed wells and from -9.9 to about $226 \mathrm{~g} \cdot \mathrm{m}^{-2} \cdot \mathrm{d}^{-1}$ for open wells (Table 4 ).

Maximum emission observed at No. 2 sampling site was several orders of magnitude lower than that measured in the areas of mud volcanoes from various locations in the world [e.g. Dimitrov, 2002; Etiope et al., 2002].

Considering all of the analyzed samples, the average emission of methane expressed by median value was $4.75 \mathrm{mg} \cdot \mathrm{m}^{-2} \cdot \mathrm{d}^{-1}$ and by mean value was $1876 \mathrm{mg} \cdot \mathrm{m}^{-2} \cdot \mathrm{d}^{-1}$. Median value is one order of magnitude higher than the values obtained for various oil/gas fields in the Polish Outer Carpathians [Sechman and Dzieniewicz, 2009]. It must be emphasized that in 2009 research the measurements were run outside the hydrocarbon exploitation areas.

\section{CONCLUSIONS}

The sampling sites of methane and carbon dioxide were located in the area of historical, abandoned Pusty Las "oil mine". Totally, 10 oil dug wells were selected for sampling, from which 4 were closed (i.e., completely filled with rubble) and 6 were still recognizable (i.e. hollows of various size). Dynamics of concentration changes of gaseous components: alkanes and carbon dioxide was determined using the static chambers methodology. The results revealed that:

- gaseous hydrocarbons detected in samples collected with the static chambers originate from deep-seated sources,

- gaseous alkanes are dominated by methane; its concentrations over the closed dug wells varied from 0.81 to $1220 \mathrm{ppm}$ and those from over the open dug wells changed from 1.1 to $288.5 \mathrm{ppm}$,

- values of methane emission from the closed wells varied from -7.8 to $18660 \mathrm{mg} \cdot \mathrm{m}^{-2} \cdot \mathrm{d}^{-1}$ and that from the open wells were from -62.2 to $42.4 \mathrm{mg} \cdot \mathrm{m}^{-2} \cdot \mathrm{d}^{-1}$,

- concentrations of carbon dioxide varied from 0.07 to 0.22 vol.\% over the closed wells and from 0.07 to 0.15 vol. $\%$ over the open wells,

- values of carbon dioxide emission from the closed wells changed from about -10 to about $47 \mathrm{~g} \cdot \mathrm{m}^{-2} \cdot \mathrm{d}^{-1}$ and then from the open wells varied from -9.9 to $225.8 \mathrm{~g} \cdot \mathrm{m}^{-2} \cdot \mathrm{d}^{-1}$,

- average methane emission was $1.9 \mathrm{~g} \cdot \mathrm{m}^{-2} \cdot \mathrm{d}^{-1}$ and average carbon dioxide emission was almost $27 \mathrm{~g} \cdot \mathrm{m}^{-2} \cdot \mathrm{d}^{-1}$,

- higher emission values of methane and carbon dioxide from the closed oil dug wells may result from microbial generation of these gases within the rubble which fills the wells; this component contributes to the flux of gases from deep sources, 

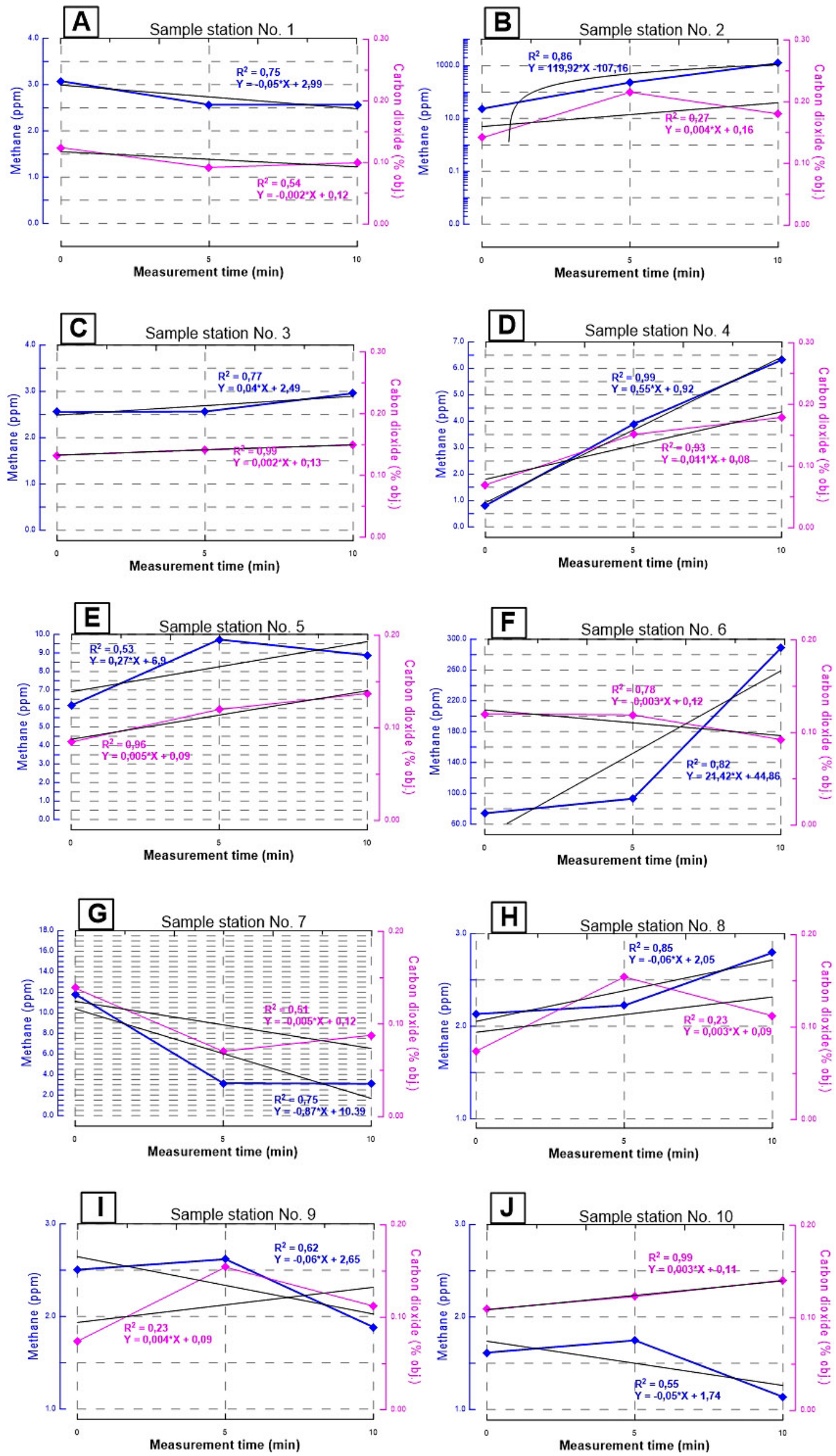

Figure 5. Dynamics of changes of concentrations measured in sample stations Nos. 1-10 (A-J) 
Table 4. Values of changes of methane and carbon dioxide concentration and emission calculated on the basis of measurements with application of static chamber method

\begin{tabular}{|c|c|c|c|c|}
\hline \multirow{4}{*}{ Item number } & \multicolumn{2}{|c|}{ METHANE } & \multicolumn{2}{|c|}{ CARBON DIOXIDE } \\
\hline & Change of concentration & $\begin{array}{c}\text { Value of methane } \\
\text { emission }\end{array}$ & $\begin{array}{c}\text { Change od } \\
\text { concentration }\end{array}$ & $\begin{array}{c}\text { Value of carbon dioxide } \\
\text { emission }\end{array}$ \\
\hline & $n^{\mathrm{CH}_{4}}$ & $E^{\mathrm{CH}_{4}}$ & $n^{\mathrm{CO}_{2}}$ & $E^{\mathrm{CO}_{2}}$ \\
\hline & $\left(\mathrm{ppm}^{*} \mathrm{~min}^{-1}\right)$ & $\left(m^{*} m^{-2 *} d^{-1}\right)$ & (\%obj. $\left.{ }^{*} \min ^{-1}\right)$ & $\left(\mathrm{g} \cdot \mathrm{m}^{-2} \cdot \mathrm{d}^{-1}\right)$ \\
\hline \multicolumn{5}{|c|}{ Closed dug wells } \\
\hline 1 & -0.05 & -7.8 & -0.002 & -10.3 \\
\hline 2 & 119.9 & 18660 & 0.004 & 16.5 \\
\hline 3 & 0.041 & 6.4 & 0.002 & 7.3 \\
\hline 4 & 0.550 & 86.6 & 0.011 & 47.3 \\
\hline \multicolumn{5}{|c|}{ Open dug wells } \\
\hline 5 & 0.271 & 42.4 & 0.053 & 225.8 \\
\hline 6 & 21.42 & 32.4 & -0.003 & -0.12 \\
\hline 7 & -0.871 & -62.2 & -0.005 & -9.9 \\
\hline 8 & 0.066 & 3.1 & -0.005 & -6.9 \\
\hline 9 & -0.062 & -2.4 & -0.004 & -4.1 \\
\hline 10 & -0.048 & -2.3 & 0.003 & 4.1 \\
\hline
\end{tabular}

- the measurements were taken within a short period of time (one week), so the seasonal changes could not have had any influence on the established emission value.

In the area of the Pusty Las "oil mine", significant methane emission occurs from abandoned oil dug wells, although average emission values were only 1 order of magnitude higher than those measured in the petroleum-prone areas in the Carpathians. Moreover, the maximum methane emission measured over one of sampled dug wells in the Pusty Las area was several orders of magnitude lower than the emissions from mud volcanoes from various localities in the world.

The results demonstrate that old oil dug wells still present in the areas of historical hydrocarbon exploitation in the Carpathians may be a significant source of greenhouse gases released to the Earth atmosphere.

\section{REFERENCES}

1. Brikenmajer K., 1977. Jurassic and Creaceous lithostratigraphic unit sof the Pieniny Klippen Belt, Carpathians, Poland. Studia Geologica Polonica $65,1-59$.

2. Dzieniewicz, M., Sechman, H., 2002. Tool kit for manual gas sampling of near-surface soil horizons. Patent no. PL 184080 B1, WUP, 08/2002 [In Polish.]

3. Dzieniewicz M., Sechman H., Kotarba M.J., Korus A., 2002.Periodical changes of methane and carbon dioxide contents in the near-surface zone along the selected four geological cross-sections of the Wałbrzych Coal District. Society of Research on Enviromental Changes „Geosphere”, Kraków, 107-135.

4. Dimitrov L.I., 2002. Mud volcanes-the most important pahway for degassing deeply buried sediments. Earth-Science Reviews 59, 49-76.

5. Etiope G., Caracausi A., Favara,R., Italiano F., Baciu C., 2002. Methane emission from the mud volcanes of Siciliy (Italy). Geophysical Research Letters 29 (8), 56 (1/4).

6. Etiope G. 2008. Natural emissions of methane from geologcal seepage in Europe. AtmospericEnvironment, 43: 1430-1443.

7. Hong Wei-Li, Etiope G., Yang F., Chang P, 2012. Methane flux from miniseepage in mud volcanoes of SW Taiwan: Comparison with the data from Italy, Romania, and Azerbaijan. Journal of Asian Earth Sciences, 01/2013, 63: 3-12.

8. Jones, V.T., Drozd, R.J., 1983. Prediction of oil or gas potential by near-surface geochemistry. American Association of Petroleum Geologist Bulletin, 67, 932-952.

9. Karnkowski P., 1999. Oil and gas deposits in Poland. Eds. W. Górecki, Geosynoptics Society, University of Mining and Metallurgy, Krakow.

10. Klusman, R.W., 1993. Soil Gas and Related Methods for Natural Resource Exploration. John Wiley \& Sons Ltd., Chichester.

11. Kuśmierek J., Machowski G., Dzieniewicz M., Sechman H., Czwarkiel P., Maruta M., Ozimek K., Pałkowska M., Pasternacki A., 2007. Study of geological-oil hydrocarbon spill in the Carpathian region. PGNiG Archives S.A., Sanok Branch. [In Polish]. 
12. Kuśmierek J., Machowski G., 2008. Oil leaks in the eastern part of the Polish Carpathians and their prognostic significance. GEOPETROL, Section I, Geology and Geophysics, 246-250. [In Polish].

13. Kopciowski R, Garecka M. 1996. The youngest pieces of the Siar-Magurian unit. Geological overview.40: 486-489. [In Polish].

14. Korus A., Kotarba M.J., Dzieniewicz M., Sechman H.,2002. Evaluation of methane and carbon dioxide flux from Upper Carboniferous coal-bearing strata to near surface zone of the Wałbrzych Coal District caused by coal mine closure: geological and geochemical controls, Society of Research on Enviromental Changes „Geospher”, Kraków, $175-188$.

15. Korus A., Kotarba M.J., Dzieniewicz M., Sechman H., 2005. Method of measuring the stream of gaseous gases emitted from the surface layers of the soil to atmospheric air (Patent Application No. P-363957). Bulletin of the Patent Office, 12 (821), 105. [In Polish]

16. Książkiewicz M., 1972. Geological structure of Poland, V Tektonik, 3, Carpathians. Geological Publishing House,1-228. [In Polish].

17. Leventhal J., 1992. Modern mobile methane measurment in marshes. United States Geological Survey, Denver, Open-File Report, 92-445, 1-24.

18. Link W. K., 1952 - Significance of oil and gas seeps in world oil exploration. Bull. AAPG, no 8, vol. 36.

19. Lipińska E., J., 2010. Places of natural flow of oil and natural gas emissions in podkarpackie. Infrastructure and ecology of rural areas. Nr 1/2010, s. 13-24. [In Polish, with English abstract].

20. Matthews, M.D., 1996. Migration - a view from the top, in: Schumacher, D., Abrams, M.A., (Eds), Hydrocarbon Migration and its Near-Surface Expression. Am. Assoc. Petrol. Geolog. Memoir 66, 139-155.

21. Mazzini A., Svensen H., Planke S., Guliyev I., Akhamanov G., Fallik T., Banks D. 2009. Whenmud volcanoes sleep: Insight from seep geochemistry at the Dasgil mud volcano, Azerbaijan. Marine and Petroleum Geology, 26(9): 1704-1715.
22. Oszczypko - Clowes M, 1999. The late Eocene to Early Miocen nannoplankton stratigraphy of the Magura Nappe (Western Carpathian, Poland). Geol. Carpath., 50: 59-62.

23. Oszczypko - Clowes M, 2001. The nanofossil biostratigraphy of the youngest deposits of the Magura Nappe (East of the Skawa river, Polish Flysch Carpathians) and their paleoenviromental conditions. Ann. Soc. Geol. Pol., 71: 139-188.

24. Oszczypko N., 2004. The structural position and tectonosedimentary evolution of the Polish Outer Carpathians. Przegląd geologiczny, 52, 780-791.

25. Pietrzycki D.: Evaluation of the emission of methane and carbon dioxide into the atmosphere in the closed area of an oil field in Siary. Master thesis. Arch. Faculty of Geology Geophysics and Environmental Protection, AGH. Kraków 2013. [In Polish, with English abstract].

26. Ryłko W., 2004. Karpaty.[W:] Pertyt T \& Piwocki M (redGeological structure of Poland, Stratigraphy, Cenozoic, Paleogene, Neogen. PIG, Warsaw: volume I, part 3a, 271-338. [In Polish].

27. Sechman H., Dzieniewicz M., Kotarba M.J. \& Korus A. 2006. Criteria of gas hazard assessment in the areas of closed mines of the Wałbrzych Coal District, Southwestern Poland. Near surface 2006: 12th European meeting of environmental and engineering geophysics, Helsinki 4-6.09.2006, P010.

28. Sechman H., Dzieniewicz M., 2009. Methane emission measurements in selected areas of the Polish Outer Carpathians. Geology, Vol. 35, issue 4/1, 129-153. [In Polish, with English abstract].

29. Świerczewska A., 2005. The interplay of the thermal and structural histories of the maguranappe (outer carpathians) in Poland and Slovakia. Mineralogia Polonica 36: 91-144.

30. Żytko K., Elias M., Nemcok J., Stranik Z., 1989. Western Outer Carpathians. In: Poprawa D., Nemcok J. [eds.] Geological atlas of the Western Outer Carpathians and their foreland. Polish Geological Institute.

31. Waleńczak, Z., 1987. Organic Geochemistry. Geological Publishing House, Warsaw. [In Polish]. 